\title{
RELATIONSHIP BETWEEN ENVIRONMENTAL FEATURES AND BIRD ASSEMBLAGES IN THE WETLANDS OF EASTERN ROMANIA
}

\author{
Ion Constantin ${ }^{1}$, Baltag Emanuel Ştefan ${ }^{1}$, Ursu Adrian $^{2}$, Sfîcă \\ Lucian$^{2}$, Ignat Alina Elena ${ }^{1}$, Stoleriu Cristian Constantin ${ }^{2}$
}

Keywords: bird assemblages, wetlands, habitat features, landscape fragmentation, weather data.

\begin{abstract}
The avian habitats in Eastern Europe are poorly managed in last decades. It is of highly noteworthy influence importance to obtain more information regarding the link between birds' presence and environmental features in wetlands to improve this poorly managed system. In our study we investigated the effects of the various habitat, landscape fragmentation and weather variables on the bird assemblages in Eastern Romania, described by diversity, species richness and abundance of non-passerine birds in wetlands. Poisson regression modelling revealed wetland area, wetland heterogeneity, proportion of open-water, density of patches and habitats, landscape shape and temperature conditions have a noteworthy influence on the bird assemblages $(\mathrm{p}<0,05)$. Our results suggest that the link between environmental features and birds' assemblage, in our study areas could be dependent on the presence of the emergent vegetation (shelter / reproduction zones), the balance between open-water area (feeding / nesting zones) and also other variables, as the temperature, the presence of the human living facilities and/or intensive fish nurseries in the neighboring zones. Waterbird distribution and abundance in eastern part of Romania are driven by similar factors to other part of the world and this study could be one of the first published on the topic in a region where It is a lack of information on waterbirds ecology. Such studies would bring valuable information about the ecologic factors influencing the lives of the birds, in the areas that were not stueid before, resulting in better conservation efforts and wetland protection, in estern part of Europe.
\end{abstract}

\footnotetext{
${ }^{1}$ Faculty of Biology, University “AlexandruIoanCuza” of Iași, Romania

${ }^{2}$ Faculty of Geography and Geology, University "AlexandruIoanCuza” of Iași, Romania
} 


\section{Introduction}

The relationships between bird assemblage and environmnetal factors are more important for nature conservation and management of bird diversity (Tews et al. 2004; Chettri et al. 2005). The bird assemblage is defined as the diversity, species richness (number of bird species) and abundance of birds (GonzálezGajardo et al. 2009). A good knowledge of biotope selectivity is essential, especially for understanding bird community relationships (Kristan et al. 2007), and for protecting the species and the wetlands (Preiszner and Csörgö 2008; Kristan et al. 2007).

Bird assemblage, especially diversity could be an excellent indicator of the effectiveness of wetlands management (Ma et al. 2010; Kahara et al. 2012), but diversity, on its own, does not offer an adequate measure of the value of wetlands (Weller 1999). Owing to this, we must often take into account the habitat heterogeneity (González-Gajardo et al. 2009), which is defined differently from author to author. Heterogeneity is considered as the diversity of habitats (the type of habitats and their surfaces) (Magurran 1988), the spatial arrangement of habitats (Schipper et al. 2011) or complexity of patch border (González-Gajardo et al. 2009; Rehm and Baldassarre 2007). Habitat heterogeneity could also stand for the variation of environmental conditions (Morrison 2006) across time and space.

Bird assemblages can be influenced by local and landscape-scale habitat features, such as wetland area (WA) (Benassi et al. 2007; Tozer et al. 2010), water depth (WD) (Colwell and Taft 2000; Bolduc and Afton 2008), perimeterto-area ratio (Fairbairn and Dinsmore 2001), shoreline development (ShD) (González-Gajardo et al. 2009), interspersion (IS) (Rehm and Baldassarre 2007), and various vegetation variables (Naugle et al. 2000). A habitat feature preference in one season may determine other choices during the rest of the year, influencing the energy reserve recovery rate and migration speed of the birds (Kristan et al. 2007; Webb et al. 2010; González-Gajardo et al. 2009). The presence of birds in a landscape in one season is highly dependent on area, be it either a suitable habitat (Andrén 1994; Skórka et al. 2006), or a spatial configuration of different habitats (Mattison and Norris 2005; Böhning-Gaese 1997), which can chang throughout the seasons. Also, the presence of nonpasserine birds in wetlands in one season is related to restrictive weather conditions (Pulido 2007). A wetland from temperate zone is on the one hand milder than the surroundings during the winter, and on the other hand it is a constant water source during arid seasons.

However, few studies have examined relationships between environmental characteristics and wetland birds in Eastern Europe in general or in Romania in particular and it is still unclear which features influence the most the bird life 
cycle (Celada and Bogliani 1993; González-Gajardo et al. 2009; Tews et al. 2004). To highlight the relationships between bird assemblages and environmental heterogeneity and to fill some degree of knowledge in this concern, we studied four different sites characterised by high variation in habitat structure. We believe that these characteristics allow us to make a comparison between them. We studied the relationships between environmental features and bird assemblages at a local level to reveal relative importance of habitat and weather characteristics on bird diversity, species richness and abundance. We assumed that the estimation errors when assessing presence of birds at a small scale were few (Rondinini et al. 2006). At local level, the study census methods could cover the entire area in a brief period, facts which do not include extrapolation errors. The fact that our estimates of local species richness and abundance are relevant in terms of conservation of wetland birds is further supported by: (1) management and conservation actions are usually implemented at small spatial scales (Fairbairn and Dinsmore 2001) and (2) local species richness could be an ecological indicator for value of wetland bird habitats (Wretenberg et al. 2010; Oja et al. 2005).

This study could be a base for future research concerning the link between the changes of the habitat features and the conservation management in existing conditions of Romania, which appear different from those in some other parts of Europe, mainly of Western Europe. In Romania, wetlands are less affected by the human impact. Furthermore, in Eastern Romania habitat resources use are very close to the traditional ones, being for the time being more environmentally friendly. In these areas, there are still used traditional agricultural and aquaculture practices, which mask the influence of intense human activity, and the relationship between birds and habitat features is less influenced throughout the phenological cycle.

The present paper aims to reveal the intricate relation between bird assemblages and environmental features in the wetlands of eastern part of Romania. Moreover, we have wanted to check if in the areas with high heterogeneity and extended areas the diversity, the number of species and the abundance of birds are also high; we have also wanted to verify if the ecological groups of representative birds for the analysed wetlands contribute differently, according to the season and the area, to the general tendency of the presence of the birds. Last, we wanted to see which of the environmental factors is correlated with the presence of the birds. In the last we tested the influence of spatial configuration of habitats (heterogeneity, shape and fragmentation) and local weather conditions on bird assemblages. Further, since climatic and habitat niches of birds are correlated (Newton 1998, p.317), we verified connections between bird assemblages and local weather conditions. 


\section{Methods}

Study area

The eastern part of Romania hosts two of the largest wetland areas in the country, the first one is the Danube Delta - Biosphere Reserve and the second one is represented by the wetlands from the Moldavian Plain. Our study area is in the north part of the Moldova region and it is focused on four artificial wetland areas: Cârja lakes, Larga Jijia lakes, Vlădeni lakes and Hălceni lake (Fig. 1). These sites were selected based on their habitat heterogeneity and their differences in management policy as they are explained below. They are located on one of the main migration routes from Romania to Africa (Ion 1992) and represent important sites for breeding and stopover during migration for many bird species.

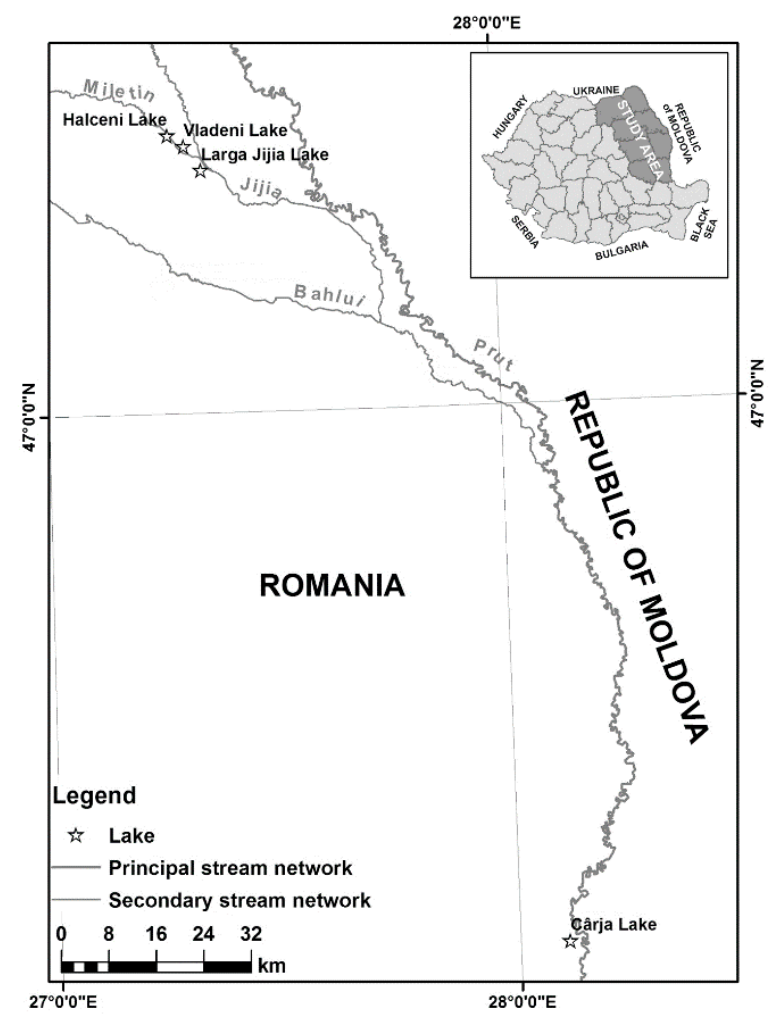

Fig. 1 Studied area, showing four wetlands (are the lakes what is being studied) of Moldova Region (Romania) 
All four wetland areas are semi-natural, with some swamp (wetlands) converted for industrial use, like aquaculture and irrigation reservoirs. Human influence in these areas peaked during their construction, but as the sites have been established, human impact is now minimal and the wetlands continue to develop naturally in these areas.

\section{Bird counts}

During winter (December, January, February), migratory seasons (spring March and April; autumn - August, September, Octomber, November) and breeding season (May, June, July) bird counts were conducted from sunrise to noon (12:00 local time), from 2009-2012. During breeding season, we survey supplimentary the breeding areas of birds of prey (species and numbers) from 15:00 local time to sunset. Number of fields trips was: 32 in 2009; 15 in 2010; 62 in 2011; 45 in 2012, respecting Double Sampling approach in every season (Thompson, 2002), as alternative to undjusted counts. We considered only nonpasserine species. In all the conducted surveys, we began near the wetlands at fixed points, where most of the surface area and the edge of the lakes was visible. We found and counted all the birds present (Bibby et al. 2000), in each season, using binoculars $(10 \times 50)$ and telescopes $(20 \times 60)$. If the weather conditions were too harsh (heavy rains, strong winds), we did not go in the field.

During the breeding season, we identified wetland colonies of aquatic bird species, and we counted individuals entering and getting-out (leaving area or entering and leaving water). We also made observations from several fixed points to enable counting of the individuals of non-colonial species (e.g. Marsh Harrier - Circus aeruginosus) and to identify bird species based on their vocalization. After the survey time, the observer walked around the perimeter of the wetland areas to identify any unseen birds. During our observations, we counted only birds which were seen in front of us. The scanning range was aprximatively about $180^{\circ}$. We avoided double counting, making abstraction by the birds behind us. The same approach was used for bird species identified by song. The number of species and abundance were figured out during each survey. The Shannon-Wiener species diversity index (Hill 1973; Krebs 1999) was calculated for each species and each site. For the diversity calculation, the abundance of every observed species was considered to be the greatest number of observed individuals per species and season (as is suggested by Le Viol et al. 2012). Species' richness was found for each site and each season. Abundance for each site and season was considered as an mean of the sum of all observed individuals across all species. We did not account the variations produced during the years due to a lack of data continuity between years. The observed 
birds were split in eight ecological groups: waterfowls (WF), waders (W), gulls and terns (GT), herons and egrets (HE), open areas birds (OAB), birds of prey (BP), forest birds (FB) and others (in the last category we included species like King Fisher (Alcedo atthis), Bee-Eater (Merops apiaster), Common Swift (Apus apus), Collared Dove (Streptopelia decaocto) and Domestic Pigeon - Columba livia forma domestica).

\section{Habitat characteristics}

In order to characterise the habitats from the studied areas, we used GIS and remote sensing methods, combining field work with laboratory digitizing and data analysis.

Using GPS devices (Garmin EX), we validated the delignation of the habitats from each wetland in every season, between 2009 and 2012. From one season to another we found insignificant differences in habitats size and only few changes in habitat type proportions (less than 10\%). Water level of our study sites did not vary significantly between spring and autumn because water volume is kept for fish farms, at a constant level by fishing companies. Reedbed management practices included freshwater inputs that promoted tall, permanently inundated reed-beds, with minimal detritus accumulation. During winter, all areas were covered by ice for some periods.

Concerning habitats, we created a geodatabase in vector format, based on aerial photographs with $0.4 \mathrm{~m}$ resolution (corresponding to 1:2000 representation scale), using MicroImages TNTmips v.7.3 and ESRI ArcGis v.9.3 software, using Universal Transverse Mercator projection system with WGS84 datum.

First, we identified in the field, specific types of birds' habitats, according to classes suggested by Crick 1992 (Fig. 2), which include the criteria for land management and human activity. Afterwards, we added specific waypoints with geographical coordinates for each habitat.

In the second step, working in the lab, we projected waypoints over aerial photography and we interpreted photographic images and we digitised, onscreen, the areas corresponding to each habitat waypoint. The scale used for onscreen digitisation was 1:300, and minimal area digitised was 0.0025 hectares. The habitats' surface areas, in hectares, were extracted from the table attached to habitats vector (see Table 1).

Apart from the wetlands, each study area includes an outer buffer zone of $500 \mathrm{~m}$ width from the lakes limits, as suggested by Tozer et al. 2010. This length $(500 \mathrm{~m})$ is the largest distance for non-passerines bird identification during our surveys by using binoculars or telescopes. 
Relationship between environmental features and bird assemblages in the wetlands 271

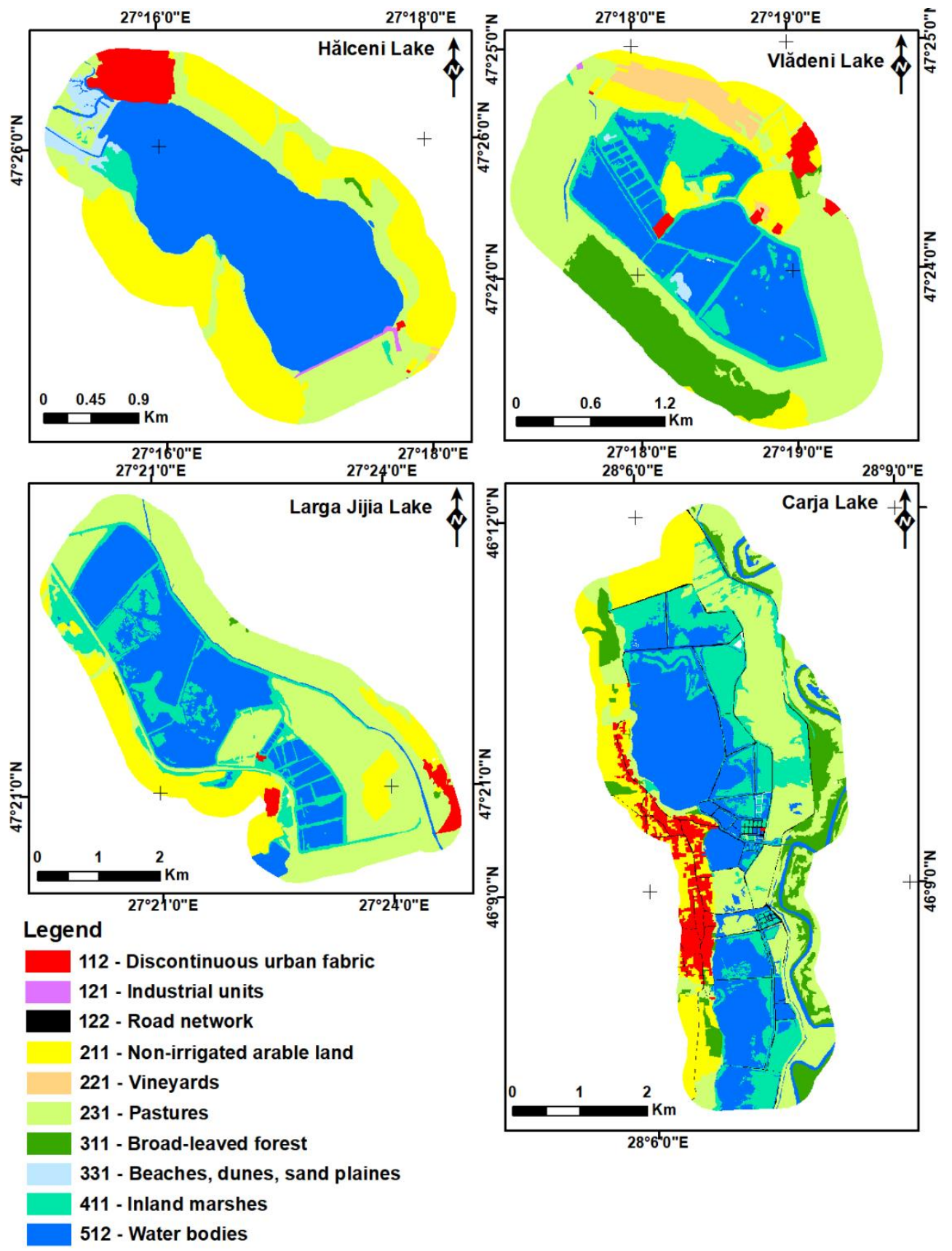

Fig. 2 The habitat types of four studied areas 
We identified ten habitat types (Fig. 2): rural human site, dam, road network, tilled land, vineyard/orchard, grassland, broad-leaved forest, gravel pit or sand pit, reed swamp, water bodies.

From the resulting vector layers with habitats we computed habitat features. Twelve physical and vegetation features (see Table 1) were calculated in each wetland: WA, wetland heterogeneity (WH), open water area (OWA), floating vegetation (FG), emergent floating vegetation (EFG), vegetation cover/open water ratio (VG/OWA), shoreline length (SL), Shoreline development (ShD), interspersion (IS), total vegetation cover (VC), area of heterogeneity (percentage cover of each type of habitat) (AH), mean water depth (Tozer et al. 2010; Bolduc and Afton 2008) (WD), and mean distance between settlements and wetlands (DSW). WD information for each study area was obtained from area administrator, and although differences in WD between seasons or years have often occurred, these differences have been insignificant $(<10 \%)$ and changed rapidly (e.g. from one day to another). For these reasons we chosen to use the mean of water depth.

Table 1 Physical and vegetation studied areas features.

\begin{tabular}{ccccc}
\hline & Cârja & Hălceni & Vlădeni & Larga jijia \\
\hline WA (ha) & 620.94 & 346.42 & 154.63 & 618.38 \\
\hline WH & 0.927537 & 0.964928 & 0.849889 & 0.85929 \\
\hline OWA \% & 11.78916 & 27.18929 & 15.63029 & 21.7626 \\
\hline FG \% & 17.88397 & 16.78939 & 10.03785 & 7.262648 \\
\hline EFG \% & 35.51276 & 18.36486 & 21.23601 & 22.77504 \\
\hline VG/OWA & 3.012323 & 0.675445 & 1.358645 & 1.046522 \\
\hline SL (m) & 199211.1 & 14185.7 & 29877.39 & 81673.86 \\
\hline ShD & 3577.868 & 273.4429 & 868.5697 & 1069.999 \\
\hline IS & 166.88 & 2.67 & 181.41 & 139.57 \\
\hline VG & 1471.66 & 441.28 & 447.79 & 1512.11 \\
\hline AH & 1.665579 & 1.366456 & 1.689804 & 1.364309 \\
\hline WD & 1.3 & 3.2 & 2.5 & 1.9 \\
\hline DSW (km) & 2.96 & 1.84 & 1.86 & 3.42
\end{tabular}

wetland area (WA), wetland heterogeneity (WH), open water area (OWA), floating vegetation (FG), emergent floating vegetation (EFG), vegetation cover/open water ratio (VC/OWA), shoreline length (SL), shoreline development (ShD), interspersion (IS), total vegetation cover $(\mathrm{VG})$, area of heterogeneity $(\mathrm{AH})$, and mean water depth (WD), distance between settlements and wetlands (DSW)

An index for the shoreline shape is given by the $\mathrm{ShD}$, with its abundance of bays which are suited to water birds (Traut and Hostetler 2004). It was calculated for each wetland area based on the following equation: 


$$
\operatorname{ShD}=\frac{S}{2 * \sqrt{a * \pi}}
$$

(Margalef 1983, described in González - Gajardo et al. 2009),

Where $\mathrm{D}=$ shoreline development, $\mathrm{S}=$ shoreline length, and $\mathrm{a}=$ open water area IS is an interface between vegetation and open water $(\mathrm{m} / \mathrm{ha})$ as described by Rehm and Baldassarre 2007. It stands for the amount of mixing between emergent vegetation and water, which create places for resting and breeding birds.

In order to describe landscape fragmentation, we calculated patch density $(\mathrm{PD}, \mathrm{n} / \mathrm{ha} ; \mathrm{n}-$ number of patches), patch richness density (PRD), n/ha ( $\mathrm{n}-$ number of habitats), landscape shape (LS, the shape of the studied area, assessed as detailed by Schipper et al. 2011), and patch shape diversity (PSD) (see Table 2). LS is calculated using the following formula:

$$
L S_{i}=\frac{P_{A_{i}}}{2 * \sqrt{\pi * A_{i}}},
$$

as suggested by Bogaert et al. 2002, where $\mathrm{S}$ is shape index, $\mathrm{P}$ is the perimeter of patch $i$, and A is the area of patch $i$, where $i$ is the study area. The PSD was calculated using the Shannon-Wiener diversity index (Hill 1973; Krebs 1999), by using information on patch shape index from study areas, calculated using Multi-Variate Statistical Package v.3.21.

Table 2 Landscape fragmentation features

\begin{tabular}{lcccc}
\hline Landscape fragmentation features & PD & PRD & LS & PSD \\
\hline Cârja & 0.003 & 0.204 & 258.003 & 2.557 \\
\hline Hălceni & 0.011 & 0.065 & 308.443 & 1.704 \\
\hline Vlădeni & 0.015 & 0.138 & 530.561 & 1.892 \\
\hline Larga Jijia & 0.003 & 0.065 & 239.232 & 2.137 \\
\hline $\begin{array}{l}\text { patch density (PD); patch richness density (PRD); landscape shape (LS); patch } \\
\text { shape diversity (PSD) }\end{array}$ & & & &
\end{tabular}

\section{Weather data}

The data referring to weather were taken from the European Climate Assessment \& Dataset ECA\&D (Klein Tank et al. 2002) free dataset and the parameters considered important for bird habitat were the mean, maximum and 
minimum daily temperatures, daily precipitation, and daily atmospheric pressure (see Table 3). The data were analysed for the same period as birdmonitoring period. The data from the ECA\&D dataset were extracted for 3 weather stations (Galați, Iași, Botoșani) covering the entire study region.

Table 3 Weather features

\begin{tabular}{cccccc}
\hline Wetlands & AT $\left({ }^{\mathbf{0}} \mathbf{C}\right)$ & MaxT $\left({ }^{\mathbf{0}} \mathbf{C}\right)$ & MinT $\left({ }^{\mathbf{0}} \mathbf{C}\right)$ & PP( $(\mathbf{m m})$ & AP $(\mathbf{m b})$ \\
\hline Cârja & 8.6 & 23.3 & -8.3 & 46.2 & 1017.6 \\
\hline Hălceni & 7.9 & 24.8 & -15.6 & 49.4 & 1018.2 \\
\hline Larga Jijia & 7.9 & 24.8 & -15.6 & 49.4 & 1018.2 \\
\hline Vlădeni & 7.9 & 24.8 & -15.6 & 49.4 & 1018.2 \\
\hline \multicolumn{6}{c}{ Summer } \\
\hline Cârja & 21.1 & 38.3 & 5.4 & 147.9 & 1012.6 \\
\hline Hălceni & 20 & 36.3 & 3.9 & 148.2 & 1013.2 \\
\hline Larga Jijia & 20 & 36.3 & 3.9 & 148.2 & 1013.2 \\
\hline Vlădeni & 20 & 36.3 & 3.9 & 148.2 & 1013.2 \\
\hline \multicolumn{5}{c}{ Autumn } \\
\hline Cârja & 15.1 & 37.6 & -6.1 & 101.2 & 1017.7 \\
\hline Hălceni & 13.8 & 38.1 & -7.9 & 119.2 & 1018.0 \\
\hline Larga Jijia & 13.8 & 38.1 & -7.9 & 119.2 & 1018.0 \\
\hline Vlădeni & 13.8 & 38.1 & -7.9 & 119.2 & 1018.0 \\
\hline \multicolumn{5}{c}{ Winter } \\
\hline Cârja & -1.8 & 17.5 & -21.5 & 137.4 & 1017.7 \\
\hline Hălceni & -2.9 & 16.6 & -26.8 & 90.6 & 1017.8 \\
\hline Larga Jijia & -2.9 & 16.6 & -26.8 & 90.6 & 1017.8 \\
\hline Vlădeni & -2.9 & 16.6 & -26.8 & 90.6 & 1017.8 \\
\hline
\end{tabular}

mean emperature (AT); maximum temperature (MaxT); minimum temperature (MinT); amount of precipitation (PP); mean atmospheric pressure (AP).

\section{Data analysis}

High-quality habitats are those categories of land-use, where many species and individuals of birds could be present (Mattison and Norris 2005). We checked if the best habitat (in terms of demographic parameters) may not necessarily be the habitat with the highest density of birds (Van Horne 1983). 
In order to emphasise the differences between bird assemblages from our studied sites we compared species richness, species diversity (Shanon-Wiener Index) and non-passerines abundance, using means and standard erors (SD). In the graph the variable, species richness and abundance were log transformed.

We realised Agglomerative hierarchical clustering (AHC) (Kaufman and Rousseeuw 1990), using Bray Curtis distance, for the bird groups in every studied area, for the abundance of four of the most representative ecological bird groups in every season and in the end, we emphasised the dissimilarity between each wetland site in each season. AHC works from the dissimilarities between the birds' ecological groups and respectively wetlands to be grouped together.

We used a Poisson regression (Stepwise model selection, likelihood criterion) (as is suggested by O'Hara and Kotze 2010) to determine habitat characteristics, landscape fragmentation features or weather conditions which could explain bird assemblages in each season. Separate analyses were performed for each dependent variable with all potential predictor variables (as is suggested by González-Gajardo et al. 2009), during each season. We used pvalue (Jongman et al, 1995) to test significance of the results. All statistical analyses were computed in Microsoft Excel by using XLSTAT package and SQL syntaxes.

\section{Results}

In the study area, from the spring of 2009 to the winter of 2012 we had recorded 123 non-passerines bird species (50\% of non-passerines species from Romania, migratory or non-migratory) (see suplimentary material).

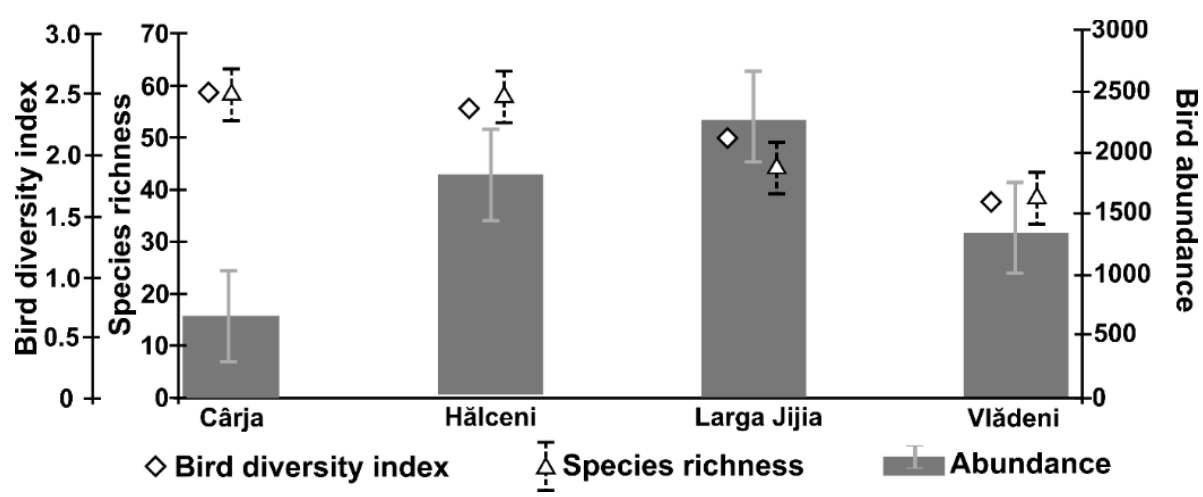

Fig. 3 Species richness, species diversity (Shannon-Wiener Index) and bird abundance by wetland, with means and Standard Error in the wetlands of the Moldova region (Romania), during 2009-2012 
When one compares the areas under observation, one can see that there are differences in the bird diversity indexes in these areas (Fig. 3), depending on the highest or smalles values of habitat values for each wetland. Cârja, the largest area (620.94 ha) with one of the highest WH index (0.92) and with the smallest OWA $(11.78 \%$ ), the highest VC/OWA ratio (3.01), had the highest values of bird diversity index (2.51), the largest number of species (59) and the lowest mean abundance (656). Hălceni, the area with highest WH index (0.96) and with the largest OWA (27.18\%), lowest VC/OWA ratio (0.67) had intermediate values to other zones, for bird diversity index (2.21), species richness (53) and mean abundance (1790). Mean bird abundance was the highest at Larga Jijia (2427), with one of the lowest WH (0.85), and with an equilibrium between VC and OWA (VC/OWA=1.04). Vlădeni, which is described by the smallest area (154.63 ha) and WH index (0.84), an intermediate value to the others for VC/OWA (1.35), had the lowest diversity bird index (1.53) and the fewest species (39).

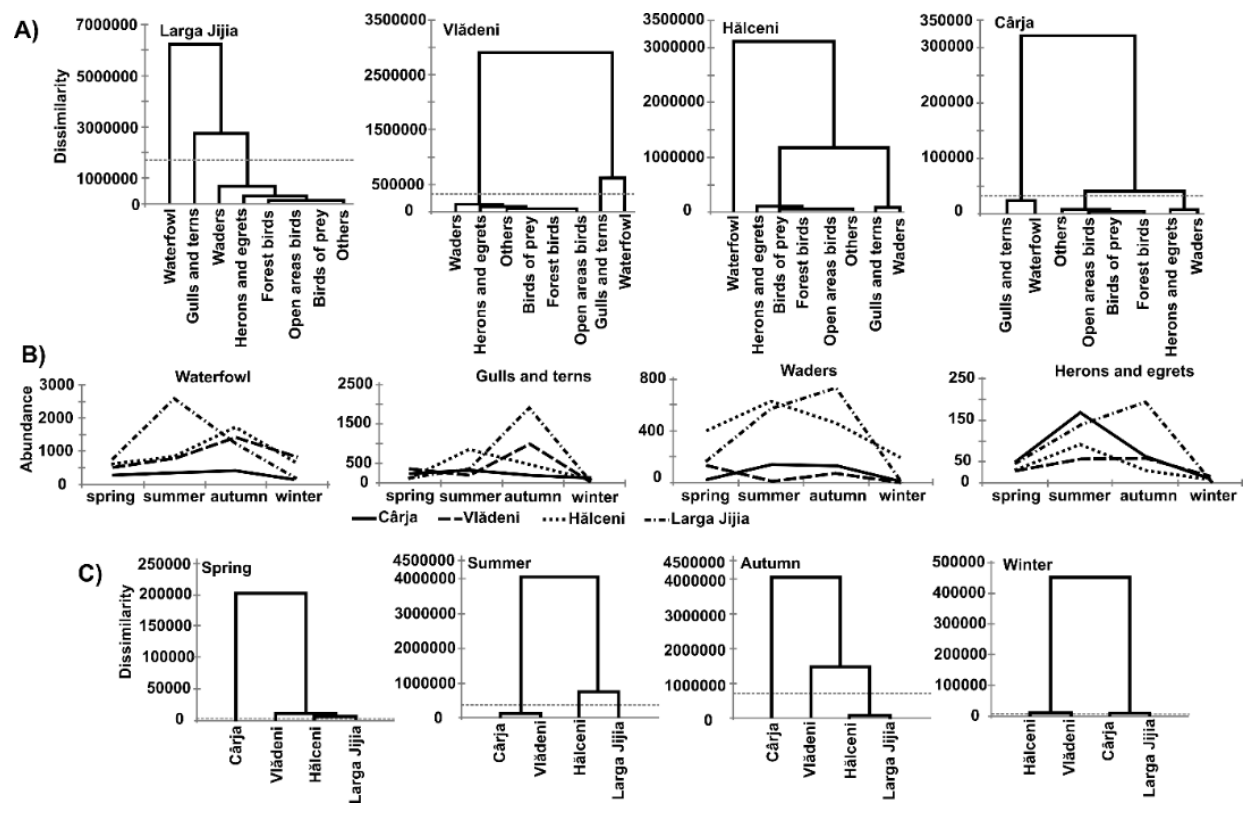

Fig. 4 Agglomerative hierarchical clustering diagram for representative ecological bird groups. Legend: waterfowls (WF); waders (W); gulls and terns (GT); herons and egrets (HE); open areas birds (OAB); birds of prey (BP); forest birds (FB). 
When we analyse the AHC dissimilation for each of the four studied areas, we see that two big clusters can be differentiated in a significant way. In one of them there are water birds which prefer shallow water, like WF, W, GT and HE; in the second one there are the birds which prefer open areas, forests and reed. Even among the ecological groups from the first category one can sees a significant dissimilation, because some of them use exclusively the water surface area or marshes (GT and W), while others also use in some proportions the areas with emergent vegetation (WF and $\mathrm{HE}$ ).

Analysing the $\mathrm{AHC}$ on main bird aquatic ecological groups for each season and lake, we saw that the lowest abundance was seen during winter. During spring migration, individual numbers is increasing, but it lasts a very brief period. The general number of birds is dwindling during summer at nesting time, and grows to the highest during autumn migration, when besides nesting individuals, some juveniles and some migrating species from the North are added (Fig. 5).

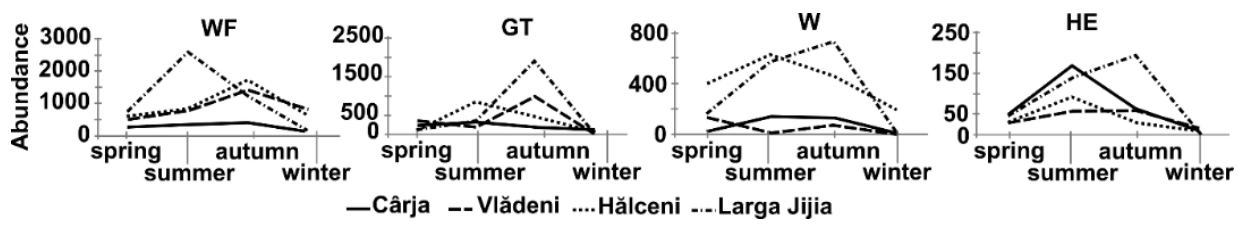

Fig. 5 Abundance of main bird ecological groups for each season. Legend: waterfowls (WF); waders (W); gulls and terns (GT); herons and egrets (HE).

WF have a different behaviour at Larga Jijia, where we can see an increased number during summer, unlike the number present in autumn in the other lakes.

GT have a bigger abundance in autumn, in Larga Jijia and Vladeni, where they have extended water areas and also shelter areas. They are also present in a larger number in Halceni in summer, where they gather especially in summer to feed themselves from those areas.

$\mathrm{W}$ are seen more often in summer and in autumn in Halceni and Larga Jijia, and their number is four times bigger than in the other two wetlands; this is caused by the existence of some widespread areas with shallow water in these areas.

HE have a bigger abundance in summer, in Carja, where they nestle and also in autumn in Larga Jijia, where they find excellent places for feeding and shelter. 
According to AHC for each studied area (Fig. 6), there is a different model according to the season. In the spring Carja shelters a vast number of species, while the other three areas have a smaller number of birds because they are geographically closed one from the other (Fig. 1), and the birds distribute themselves uniformly.
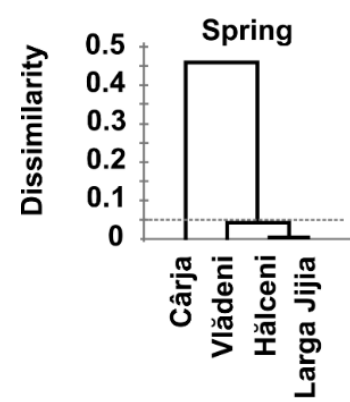

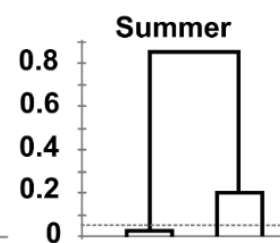

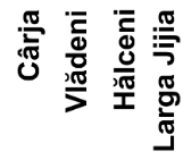

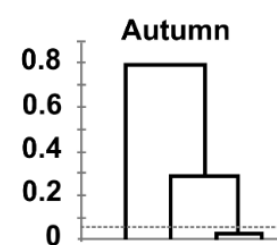

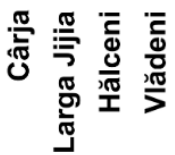

Winter
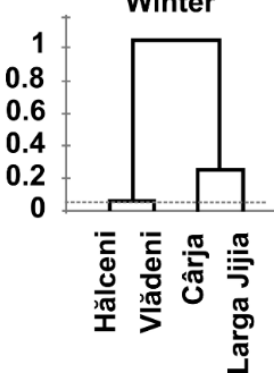

Fig. 6 Agglomerative hierarchical clustering diagram for each studied area

In the nesting period, Larga Jijia and Halceni are significative different. Larga Jijia is favourable for nesting, having larger areas with reed (see Table 1), and at Halceni the number of birds is low. Most of the birds that are present here to feed themselves in this period and come from Vladeni and Larga Jijia or other close areas with which these wetlands have connections. Carja and Vladeni have a lower number of species than Larga Jijia in the summer and although they differ when it comes to the surface (see Table 1), the differences are not so high when it comes to the abundance of birds.

In autumn, Larga Jijia and Carja are significant different from other areas because they have larger areas which can offer support for a larger number of birds which are migrating.

In the winter, Halceni differs from the rest of the lakes because it has bigger water surface area, as it is described above, and higher WD $(3.42 \mathrm{~m})$ (see Table 1), which freezes only in some years and for a relative brief period of time. Carja and Larga Jijia are also different because, at Carja, being positioned in a southern part, the temperature conditions are gentler and so it offers the possibility of birds to stay and shelter here for a longer period of time during winter.

We can draw some models from the AHC analyse. The ecological bird groups which characterises the best the abundance of water birds in the studied areas are WF, W, GT and HE. Those areas with a bigger surface with high percentage of vegetation cover have more individuals as Carja and Larga Jijia during seasons without ice. At Halceni, birds have feeding conditions even 
during the winter, since the water hardly freezes because of the extended OWA water surface. On the other hand, at Vladeni, because it is small and with low $\mathrm{WH}$, the number of birds is reduced.

Table 4 Environmental models using stepwise Poisson regression. Environmental features enter the analysis with significance $\mathrm{p}$ value $<0.05$.

\begin{tabular}{|c|c|c|}
\hline Bird variables & Environmental variables & $\begin{array}{l}\mathbf{p} \\
\text { value }\end{array}$ \\
\hline \multicolumn{3}{|l|}{ Spring } \\
\hline & \multicolumn{2}{|l|}{$\begin{array}{l}\text { Pred(Abundance })=\exp (9,04055-0,00038 * \text { Wetland area-3,23182*Wetland } \\
\text { heterogenity }+0,04497 * \text { Open water area \%) }\end{array}$} \\
\hline \multicolumn{3}{|c|}{$\begin{array}{l}\text { Summer } \\
\text { Pred(Species richness })=\exp (3,93937+0,00072 * \text { Wetland area-0,01243*Open water area } \%)\end{array}$} \\
\hline Species richness & $=\exp (4.06340-26.15197 * \mathrm{PD}+1.39936 * \mathrm{PRD})$ & 0.044 \\
\hline Species richness & $=\exp (-2.46383+0.32011 * \mathrm{AT})$ & 0.015 \\
\hline $\begin{array}{l}\text { Autumn } \\
\text { Pred(Species ric } \\
0,01548 * \text { Open wat } \\
\text { Pred(Abundance) } \\
\text { heterogenity+0,09: }\end{array}$ & 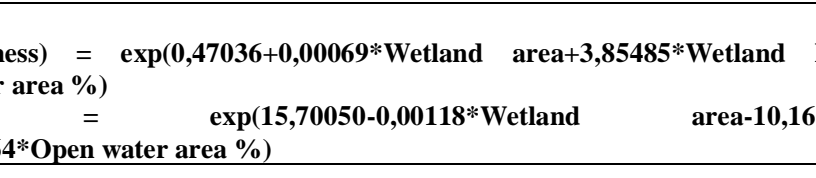 & $\begin{array}{l}\text { heterogenity- } \\
6590 * \text { Wetland }\end{array}$ \\
\hline Species richness & $=\exp (0.47036+0.00069 * \mathrm{WA}+3.85485 * \mathrm{WH}-0.01548 * \mathrm{OWA} \%)$ & 0.005 \\
\hline Species richness & $=\exp (4.42282+51.93290 * \mathrm{PD}+3.44720 * \mathrm{PRD}-0.00386 * \mathrm{LS})$ & 0.005 \\
\hline Species richness & $=\exp (-0.90660+0.34418 * \mathrm{AT})$ & 0.003 \\
\hline \multicolumn{3}{|c|}{$\begin{array}{l}\text { Winter } \\
\text { Pred(Species richness) }=\exp (-6,76092+11,45847 * \text { Wetland heterogenity- } 0,01550 * \text { Open water area } \%) \\
\text { Pred(Abundance) }=\exp (1,08485-0,00364 * \text { Wetland } \\
0,00402 * \text { Open water area } \%)<0,0001\end{array}$} \\
\hline Species richness & $=\exp (-6.76092+11.45847 * \mathrm{WH}-0.01550 * \mathrm{OWA} \%)$ & $<0.0001$ \\
\hline Species richness & $=\exp \left(4.50776+250.66777 * \mathrm{PD}+7.76355^{*} \mathrm{PRD}-0.01231 * \mathrm{LS}\right)$ & $<0.0001$ \\
\hline Species richness & $=\exp (4.37295+0.38004 * \mathrm{AT})$ & 0.036 \\
\hline Abundance & $=\exp (5.70030+286.88946 * \mathrm{PD}+4.20727 * \mathrm{PRD}-0.00703 * \mathrm{LS})$ & $<0.0001$ \\
\hline Abundance & $=\exp \left(4.25079-0.76756^{*} \mathrm{AT}\right)$ & $<0.0001$ \\
\hline
\end{tabular}

As a general observation, for the spring season there were not any correlations (see Table 4). We also did not find a significant correlation between environmental variables and diversity index of non-passerine birds. The data suggest that species richness may be influenced environmental variables, except for spring, and birds' abundance mainly during winter-time. The increase 
number of species richness was influenced by WA, WH and the decrease of species by OWA, as well in autumn $(\mathrm{p}=0.005)$ and in winter (except WA) $(\mathrm{p}<0.0001)$. Additionally, we found that species richness was best predicted by PD and PRD in summer ( $\mathrm{p}=0.044)$, and also by LS for autumn $(\mathrm{p}=0.005)$ and winter $(\mathrm{p}<0.0001)$. Abundance was best predicted only in winter by PD, PRD and LS $(\mathrm{p}<0.0001)$. PD and PRD were positively correlated with species richness and abundance for these cases and with LS, negatively.

Regarding weather, AT was the most important predictor for species richness in autumn $(\mathrm{p}=0.003)$ and winter $(\mathrm{p}=0.036)$, and for abundance, only in winter $(\mathrm{p}<0.0001)$, positively correlated with these.

\section{Discussion}

When it comes to the presence of bird species in wetlands with high heterogeneity, the highest bird diversity, and species richness were recorded in areas with one of the highest habitat heterogeneity and the largest area, as we found at Carja. We believe that this is due to the fact that in these areas birds could find ecological niches large enough to breed and feed. This observation is different with the one published data by Picketta and Siriwardena in 2011 or Tews at al. 2004, which suggested that some specialized bird species appear to avoid heterogeneous landscapes. In Cârja habitats are less fragmented but sufficiently wide to ensure suitable conditions for high species diversity. The lowest abundance rate was in Cârja. We believe that this is due to two factors: 1. there is extensive human habitation near the lake Carja, roughly six times more numerous than Larga Jijia (as is observed in Fig. 2); 2. there is intensive fish farming in the water basins and the workers here are constantly chasing-out the birds to protect the schools of baby-fish. In addition, the wetland in Cârja has the smallest open-water area, resulting in a reduced feeding surface compared with other areas. The combination of these factor results in the birds visiting the water zone infrequently, for a brief period, and in small groups.

The highest non-passerines abundance was found in Larga Jijia, where there are vast open water surfaces and a balance between the habitats, far from human habitation and where humans have limited access (the numbers in table 1 support this).

The Hălceni wetlands have a large water-basin, deep waters with scarce emergent vegetation, an ideal habitat for birds to migrate and stay during winter. Hălceni wetlands have deep water on the open-water areas, which ensures a high thermic inertia, so the water is less likely to freeze, offering a warmer environment for feeding during the winter. 
Our data show that Vlădeni wetland is suitable for few birds compared to other wetlands during breeding, migration, and spending time there over-winter, because it is too small.

Comparing and contrasting the bird assemblages in studied areas, we observed that the ideal habitat has a balance between OWA and it is covered by vegetation areas or those dominated by emergent vegetation, as proven by the findings from Larga Jijia or Carja, respectively. There is an assumption (González-Gajardo et al. 2009) that birds need a certain physical open-space for feeding, and another vegetation-covered space for getting cover in case of danger and nesting.

Even so, we believe that the ecological group and the season are important in concordance with what Katayama et al., 2014, has mentioned. The larger the ecological spectrum of the bird group is (as GT and W), the more present it is in all the wet areas, where there is not only a larger proportion of OWA, where they feed, but also of reed where they cover. The more depended it is of reed (WF and HE) while nesting, the more they will look for areas dominated by reed (Carja and Vladeni), or in which there is an equilibrium between $\mathrm{VC}$ and OWA (Larga Jijia).

Apart from the importance of wetlands and of the ecological groups that are present there, the environment variables act upon the presence of birds depending on the season. WA, WH and OWA were important to bird species in our results. Other studies confirm that WA and WH area are essential for birds (Fairbairn and Dinsmore 2001; Riffel et al. 2001, González-Gajardo et al. 2009; Celada and Bogliani 1993). The spring migration is very fast, birds try to find their nesting area, which for most of them are further north than our study areas, so that wetland features does not have a considerable influence on the presence of the birds. The bird species prefer the habitat that is important for their nesting period. During the breeding period, bird species showed specialised behaviour by selecting favourable habitats (Batt et al. 1992), while during other seasons, they are typically generalists. During autumn-time, species number increases with increased wetlands surface and heterogeneity, and with a reduced openwater surface, but they do not go where OWA is dominated, unlike their behaviour in the cold season. During winter-time the bird species richness is related to smaller OWA, surrounded by emergent vegetation and provide shelter and food for a lot of individuals. In the meantime, a bigger diversity of habitats with emergent vegetation gives shelter during extremely wintry weather and fierce winds.

Our results show that landscape model is important in summer, autumn, and winter, supporting earlier observations that wetlands characteristics are more influential in these three seasons. It appears that during the spring the 
landscape model does not influence birds' search for preferred habitat, or they are quickly passing by towards more northern nesting areas. The degree of habitat fragmentation does not seem to be relevant, because the rule of the first male that comes is respected in delimiting the nesting territory. Birds do not have enough time to search for preffered habitat, being more focused on feeding and flying fast, further to the breeding area.

During summer and winter, the number of birds' species increases with increased PD and PRD and habitat types, as Andrén 1994 previously described. He said that not only the size and isolation of a patch is significant, but also the surrounding habitats. The number of species and the abundance are dwindling with the increased irregularity (LS) of area landscape shape, in opposition with what González-Gajardo et al. 2009 mentions. Probably the areas studied by us are on a main migratory route (Ion, 1992), in another climatic area that the ones mentioned by González-Gajardo et al. 2009, which is in concordance with what Katayama et al., 2014 mentioned. The birds often search for areas with shallow water where they can feed themselves, areas that are met especially at the end of lakes or reed areas for shelter, in conditions with high nebulosity and areas that are less influenced by the winding lines between habitats. The number of species and their abundance are greater in large water basins with a regular shape, like that of Hălceni, Carja or Larga Jijia, encompassing a large OWA, standing for a good support for birds.

The relationship between weather conditions and habitat features is still unclear in the literature (Barnagaud et al. 2012; Pearson and Dawson 2003), but it appears that climatic variables may play an influential role in explaining bird assemblages (Triviño et al. 2011). Temperature influence birds' assemblage through complex pathways of biotic interactions involving effects on resource levels, population densities, competition, predation, and can decide local species densities (Lennon et al. 2000). Our results show the key role of weather temperature during autumn and winter. The autumn migration happens during a larger period of time, from August to November, and birds may survive several days in conditions of cold and rain, without feeding, during chilly air and advection fog, which are common in this period. During mild weather, migratory birds stop their migration for feeding and moulting and they move towards south, just before severe weather conditions arrive.

The winter has a harmful effect on the bird abundance, when the lakes are usually frozen, and the number of species using open water dwindles dramatically. It should be noted that recent increases in streamflow during the winter for Romania (Bârsan et al. 2014) tends to reduce the frozen periods of the lakes in winter which can have a major impact on birds. 
However, we must emphasize as a firm conclusion that temperature plays on its own a leading role for species richness and abundance. The air temperature influences the number of species along the biologic cycle (Newton 2007). In northern hemisphere, the weather is harsh due to day-to-day weather changes, therefore birds that come from wintering areas could be affected (Newton 2007), as well as in autumn when they move towards south. Also, very low or elevated temperatures during summer can increase bird mortality, especially that of juveniles (Newton 2007). The air temperature plays a very important role as mentioned by Gauthreaux et al. 2005, due to the correlation between air pressure and precipitation. In this manner, low pressure systems generate high amount of precipitation which can slow the birds' migration leading mainly to a decrease of time intervals available for feeding. This is very possible in our study area especially in November, a month well known for the high frequency of Mediterranean cyclones (Sfîcă and Garaba 2014).

WA, WH, proportion of OWA, PD and PRD, LS and weather conditions appear to exert a considerable influence on bird assemblages in the wetlands of Eastern Romania. Our results are concordant with some published results of González-Gajardo et al. 2009, Andrén 1994, Dallimer et al. 2012, Tozer et al. 2010, Barnagaud et al. 2012. However, the relationship between habitat features and bird assemblages in the wetlands should focus not only on biodiversity and habitat choice, but also on the analysis of the relationships between different biogeographic factors, land use, human effects, and climatic variables (Le Viol et al. 2012; Riffell et al. 2001), but also with research on ecological niches specific to the wildlife concerned (Kristan et al. 2007; Báldi 2006; Tews et al. 2004). In general, other crucial factors may be involved (Pearson and Dawson 2003), such as biotic interactions, evolutionary change, dispersal ability, degree of human development, surrounding landscape, and differences in water chemistry or hydrologic regimes. Land managers interested in water bird management or conservation should consider focusing their efforts on landscapes with copious amounts of emergent vegetation and keeping high degree of water-vegetation interspersion within the wetland (Bolenbaugh et al. 2011), and our data supports similar efforts. Furthermore, bird studies should be incorporated into future wetland management practices (Martinez-Vilalta et al. 2002).

Bird studies prove that vegetation physiognomy positively is important to species diversity (Tews et al. 2004). Special attention should be given also to the habitat categories that delimitate the wetlands. A limited degree of land fragmentation can lead to higher reproductive success for birds (Stephens et al. 2003). Since reed-beds are important habitats for several bird species, and abundance of these species appears to be influenced by vegetation structure 
(Báldi 2006; Paracuellos 2008; Dallimer et al. 2012), in bird conservation efforts, it is essential to maintain a degree of heterogeneity in wetlands, but at the same time not to cause a higher degree of landscape fragmentation.

In summary, our results suggest that the link between habitat characteristics and birds' assemblage, in our study areas could be dependent on the presence of the emergent vegetation (shelter / reproduction zones), the balance between open-water area (feeding / nesting zones) and other variables as the presence of the human living facilities and/or intensive fish nurseries in the neighbouring zones.

Our results support the notion that there is a strong need for monitoring the East-European wetlands, where human habitation and industrial activities are different than in other areas of the world. Such studies would bring valuable information about the ecologic factors influencing bird lives, resulting in better conservation efforts and wetland protection.

Acknowledgements: We are grateful to those who have helped us in the field: Lucian Bolboacă, Laurențiu Petrencu, Lucian Fasolă. We thank PhD. Almoș Bela Trif, Ph.D. Michael Parker, Ph.D. Cristian Patrichi, Iulian Iordache and Ph.D. Ștefan Zamfirescu and an anonymous referee for their helpful comments on an earlier version of this manuscript. The authors received no specific funding for this work.

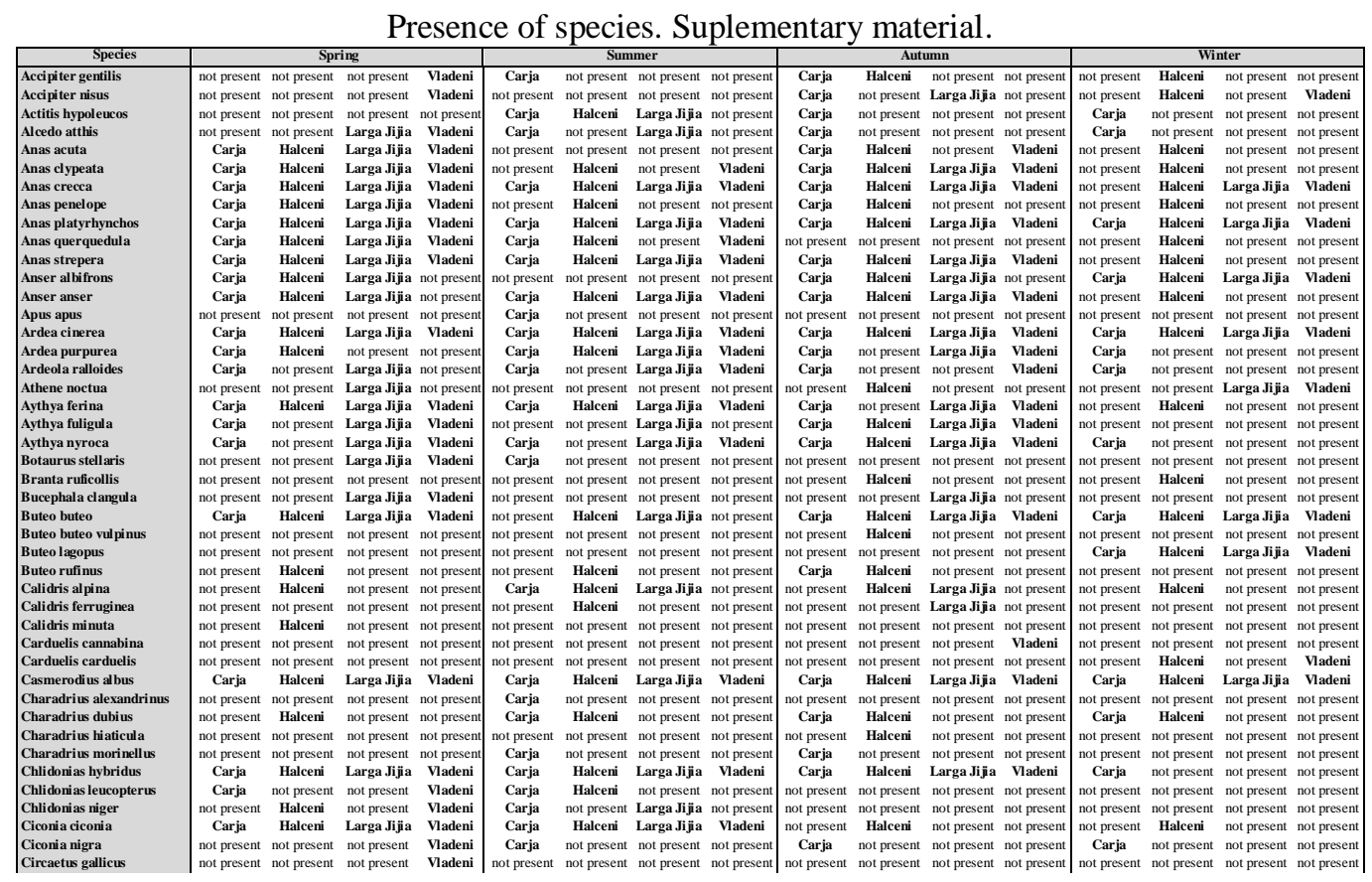


Relationship between environmental features and bird assemblages in the wetlands 285

\begin{tabular}{|c|c|c|c|c|c|c|c|c|c|c|c|c|c|c|c|c|}
\hline $\begin{array}{l}\text { ruginosus } \\
\text { neus }\end{array}$ & $\begin{array}{l}\text { Carja } \\
\text { Carja }\end{array}$ & $\begin{array}{l}\text { not present } \\
\text { not present }\end{array}$ & $\begin{array}{l}\text { Larga Jijia } \\
\text { not present }\end{array}$ & esent & $\begin{array}{c}\text { Carja } \\
\text { not presen }\end{array}$ & $\begin{array}{c}\text { Halceni } \\
\text { not present }\end{array}$ & $\begin{array}{l}\text { ga Jijia } \\
\text { present }\end{array}$ & $\begin{array}{c}\text { Vadeni } \\
\text { not present }\end{array}$ & $\begin{array}{l}\text { Carja } \\
\text { Carja }\end{array}$ & $\begin{array}{l}\text { not present } \\
\text { not present }\end{array}$ & 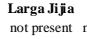 & resent] & $\begin{array}{l}\text { Carja } \\
\text { Carja }\end{array}$ & $\begin{array}{l}\text { not present } \\
\text { Halceni }\end{array}$ & $\begin{array}{l}\text { not present } \\
\text { not present }\end{array}$ & \begin{tabular}{|l|l} 
oto present \\
Vladeni
\end{tabular} \\
\hline & present & not present & Larga Jijia & & not present & not present & not present $n$ & not present & not present & not present & not present & present & \begin{tabular}{|l|} 
not preserer \\
\end{tabular} & not present & not present & $\begin{array}{c}\mathrm{t} \text { present } \\
\text { tat }\end{array}$ \\
\hline vertion & present & not present & not present & not prese & not present & not present & not present $n$ & not present & Carja & not present & present n & resent & not present & present & not present & present \\
\hline $\begin{array}{l}\text { a domestica } \\
\text { umbus }\end{array}$ & $\begin{array}{l}\text { present } \\
\text { rosents }\end{array}$ & not present & not present & $\begin{array}{l}\text { not prese } \\
\text { not reses }\end{array}$ & $\begin{array}{l}\text { Carja } \\
\text { Caria }\end{array}$ & $\begin{array}{l}\text { not present } \\
\text { not present }\end{array}$ & not present $n$ & not present & Carja & present & present n & resent & not present & present & not present & present \\
\hline & present & & Larga Jijia & not pre. & $\begin{array}{l}\text { Carja } \\
\text { atesent }\end{array}$ & not present & Larga Jijia & Vladeni & not present & not present & not present $n$ & not present & not present & not present & not present & not present \\
\hline & & $\begin{array}{l}\text { t present } \\
\text { tresents }\end{array}$ & 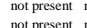 & 然 & $\begin{array}{l}\text { not present } \\
\text { Carja }\end{array}$ & $\begin{array}{l}\text { not present } \\
\text { not present }\end{array}$ & $\begin{array}{l}\text { ga Jijia } \\
\text { resent }\end{array}$ & $\begin{array}{c}\text { not present } \\
\text { not resent }\end{array}$ & $\begin{array}{l}\text { not present } \\
\text { not resent }\end{array}$ & $\begin{array}{l}\text { not present } \\
\text { not present }\end{array}$ & $\begin{array}{l}\text { not present } \\
\text { not resent }\end{array}$ & $\begin{array}{c}\text { not present } \\
\text { not resent }\end{array}$ & not present & not present & not present & not present \\
\hline rex & $\begin{array}{l}\text { tipsesent } \\
\text { t present }\end{array}$ & $\begin{array}{l}\text { not present } \\
\text { not present }\end{array}$ & $\begin{array}{l}\text { not present } \\
\text { not present }\end{array}$ & Vladeni & not present & $\begin{array}{l}\text { not present } \\
\text { not present }\end{array}$ & $\begin{array}{l}\text { not present } \\
\text { not present }\end{array}$ & $\begin{array}{c}\text { not present } \\
\text { not present }\end{array}$ & $\begin{array}{l}\text { not present } \\
\text { not present }\end{array}$ & $\begin{array}{l}\text { not present } \\
\text { not present }\end{array}$ & $\begin{array}{l}\text { not present } \\
\text { not present }\end{array}$ & $\begin{array}{c}\text { not present } \\
\text { not present }\end{array}$ & $\begin{array}{l}\text { not present } \\
\text { not present }\end{array}$ & $\begin{array}{l}\text { not present } \\
\text { not present }\end{array}$ & $\begin{array}{l}\text { not present } \\
\text { not present }\end{array}$ & $\begin{array}{l}\text { not present } \\
\text { not present }\end{array}$ \\
\hline$x_{0}$ & t present & not present & Larga Jijija & Vadeni & Carja & not present & not present & Vladeni & not present & not present & not present & not present & not present & not present & not present & not present \\
\hline & & resent & & & not present & not present & Larga Jijia $n$ & & not present & not present & not present & Vladeni & Carja & not present & not present & not present \\
\hline & Carja & Halceni & Larga Jijija & Vladeni & Carja & Halceni & Larga Jijia & Vladeni & Carja & Halceni & Larga Jija & Vladeni & Carja & Halceni & Larga Jijia & Vladeni \\
\hline & & not $\mathrm{p}$ & Larga Jijia & Vladeni & not present & not pres. & not present $n$ & not present & Carja & not present & Larga Jijia & not present & Carja & not present & not present & not present \\
\hline & & not present & & & not present & not present & not present $n$ & not present & not present & not present & not present $n$ & not present & Carja & not present & not present & not present \\
\hline & ient & not present & Larga Jijia & not preser & Carja & not present & not present & Vladeni & Carja & & not present $n$ & resent & Carja & esent & not present & adeni \\
\hline & & Halceni & Larg & not prese & Carja & Halceni & Larga Jijia & Vladeni & Carja & ceni & Larga Jija a & deni & Carja & Halceni & not present & resent \\
\hline & & & & & not presen & & & not present & Carja & & & & & & & \\
\hline & & & & & Carja & & & & Carja & & not present & & not present & & & resent \\
\hline aco & ent & 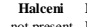 & jia & Vladeni & Carja & 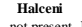 & ent $n$ & resent & Carja & eni & ent $n$ & sent & rja & eni & & sent \\
\hline ore & & & & esent & not presen & not & & resent & not present & esent & & esent & not present & & & esent ] \\
\hline dic & $\mathrm{Ca}$ & Halceni & ia & Vladeni & Carja & & Jijia & Vladeni & Carja & Halceni & Larga Jijia & deni & Carja & Halceni & not present & deni \\
\hline & ${ }_{n}^{\text {not }}$ & $\mathrm{Ha}$ & & & not present & not & resent in & not present & not present & eni & & resent & not present & cenii & & \\
\hline $\begin{array}{l}\text { allina } \\
\text { allinu } \\
\text { a }\end{array}$ & & $\begin{array}{l}\text { Halceni } \\
\text { Halaceni }\end{array}$ & $\begin{array}{l}\text { not present } \\
\text { not rot resent }\end{array}$ & $\begin{array}{c}\text { Vadeni } \\
\text { Vladeni }\end{array}$ & $\begin{array}{l}\text { Carja } \\
\text { Carja }\end{array}$ & $\begin{array}{l}\text { Halceni } \\
\text { Halaceni }\end{array}$ & & $\begin{array}{r}\text { Vadeni } \\
\text { Vladent }\end{array}$ & \begin{tabular}{|l} 
Carja \\
\end{tabular} & Halceni & & $\begin{array}{r}\text { Vladeni } \\
\text { VIadent }\end{array}$ & & eni & ot present & esent \\
\hline pus & & $\begin{array}{l}\text { Halceni } \\
\text { - }\end{array}$ & $\begin{array}{l}\text { not present } \\
\end{array}$ & & Carja & & Larga Jijia & Vladeni & Carja & Halceni & Larga Jija & Vladeni & Carja & not present & not present & resent \\
\hline arrul & $\begin{array}{l}\text { not present } \\
\text { not present }\end{array}$ & $\begin{array}{l}\text { not present } \\
\text { not present }\end{array}$ & $\begin{array}{l}\text { not present } \\
\text { not present }\end{array}$ & $\begin{array}{c}\text { not present } \\
\text { not present }\end{array}$ & $\begin{array}{c}\text { not present } \\
\text { not present }\end{array}$ & $\begin{array}{l}\text { not present } \\
\text { not present }\end{array}$ & $\begin{array}{l}\text { not present } \\
\text { not present }\end{array}$ & $\begin{array}{l}\text { not posent } \\
\text { not present }\end{array}$ & $\begin{array}{l}\text { Carja } \\
\text { Carja }\end{array}$ & $\begin{array}{l}\text { not present } \\
\text { Halceni }\end{array}$ & $\begin{array}{l}\text { ont present } \\
\text { not present }\end{array}$ & $\begin{array}{c}\text { not present } \\
\text { not resent }\end{array}$ & $\begin{array}{l}\text { not present } \\
\text { not present }\end{array}$ & $\begin{array}{l}\text { notpresent } \\
\text { not present }\end{array}$ & $\begin{array}{l}\text { not present } \\
\text { not present }\end{array}$ & resent \\
\hline & sent & not present & not present & not present & $\begin{array}{l}\text { not presestive } \\
\text { not }\end{array}$ & not present & $\begin{array}{l}\text { not presesent } \\
\text { not }\end{array}$ & not present & \begin{tabular}{|l} 
Carja \\
not present
\end{tabular} & Halceni & not present & not present & $\begin{array}{l}\text { not poresent } \\
\text { not present }\end{array}$ & not present & $\begin{array}{l}\text { not present } \\
\text { not present }\end{array}$ & esent \\
\hline & & . & & not present & Carja & & & not present & Carja & & not present & not present & not present & Halceni & Larga Jiji & $\begin{array}{l}\text { plesesent } \\
\text { ladeni }\end{array}$ \\
\hline & & Hal & & Vladeni & Carja & Halceni & & resent] & Carja & present & not present n & resen & not present & Halceni & & \\
\hline & & & Larga. & not presen & Carja & & ia & Vladeni & Carja & & not present $n$ & reser & not present & not present & not $\mathrm{p}$ & \\
\hline & & & & & Carja & & & & not present & & & esen & not present & & & \\
\hline & & & & & Carja & & & & & & & & & & & \\
\hline $\mathrm{r}$ & & & & Vladeni & & & & & & & & & & & & \\
\hline & & & & & & & & & & & & & & & & \\
\hline & & not present & & not present & not present & resent & & not present & not present & & & & esent & & & \\
\hline anus & & not presen & & not present & Carja & nt & int $\mathrm{n}$ & & & & & & & & & \\
\hline Irus r & & & Larga & & $\mathrm{Ca}$ & & & & & & & & & & & \\
\hline $\begin{array}{l}\text { alimosa } \\
\text { sulterluse }\end{array}$ & & Ha & & Vadeni & & & & & & & & & & & & \\
\hline ser & ent & $\begin{array}{l}\text { Halcer } \\
\text { not pres }\end{array}$ & $\begin{array}{l}\text { not } \\
\text { not }\end{array}$ & te & $\begin{array}{l}\text { not present } \\
\text { not present }\end{array}$ & $\begin{array}{l}\mathrm{n} \\
\mathrm{n}\end{array}$ & $\begin{array}{l}\text { ent } \\
\text { ent } \\
\text { ent }\end{array}$ & $\begin{array}{l}\text { not poserent } \\
\text { not present }\end{array}$ & $\begin{array}{l}\text { not posenent } \\
\text { not resent }\end{array}$ & $\begin{array}{c}\text { not present } \\
\text { Halcenit }\end{array}$ & $\begin{array}{l}\text { ent } \\
\text { ent } n \\
\text { ent }\end{array}$ & $\begin{array}{c}\text { not present } \\
\text { not resent }\end{array}$ & $\begin{array}{l}\text { not present } \\
\text { not present }\end{array}$ & $\begin{array}{l}\text { not present } \\
\text { not prest }\end{array}$ & $\begin{array}{l}\text { not present } \\
\text { not present }\end{array}$ & t t present \\
\hline & & not present & not 1 & not present & Carja & Halceni & & Vladeni & Carja & Halceni & not present & Vladeni & Carja & not present & not present & th tresenent \\
\hline & & & & & not pres & & & Vladeni & not present & not & not & sent & not $\mathrm{p}$ & not p & not $\mathrm{p}$ & $\begin{array}{c}\text { not present } \\
\text { not present }\end{array}$ \\
\hline & & & & & Carj & $\mathrm{H}_{3}$ & & Vadeni & Car & Hal & & & $\mathrm{Ca}$ & Halceni & & \\
\hline & & & & & not prese & & & & not pric & & & & not $\mathrm{p}$ & & & present \\
\hline & & & & & Carja & & & & Carja & & & & & & & \\
\hline & & & & & Car. & & & & $\mathrm{Ca}$ & & & & sent & & not $\mathrm{p}$ & \\
\hline & & & & & $\mathrm{Ca}$ & & & & $\mathrm{Ca}$ & & & & & & & \\
\hline & & & & & $\mathrm{Car}$ & & & & $\mathrm{Ca}$ & & & & -4 & & & \\
\hline & & & & & not pre & & & & & & & & & & & \\
\hline & & & & & $\mathrm{Ca}$ & & & & & & & & & & & \\
\hline & & & & & $\mathrm{Ca}$ & & & & & & & & & & & \\
\hline 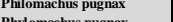 & & & & & $\mathrm{Ca}$ & & & & & i & & & & & & \\
\hline nax & ent & $\mathrm{Ha}$ & not & n & not $\mathrm{p}$ & 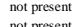 & $\mathrm{n}$ & ent & not $\mathrm{p}$ & & & & & & & \\
\hline & & & & ph & $\begin{array}{l}\text { not present } \\
\text { not present }\end{array}$ & & & & $\mathrm{Ca}_{\mathrm{O}}$ & & & & & & & \\
\hline & & & & $\begin{array}{l}\text { loderen } \\
\text { lladeni }\end{array}$ & $\begin{array}{l}\text { not present } \\
\text { Carjat }\end{array}$ & $\begin{array}{c}\text { not pi } \\
\text { Hal }\end{array}$ & & $\begin{array}{c}\text { not present } \\
\text { Vladeni }\end{array}$ & $\begin{array}{l}\text { Car } \\
\text { Car }\end{array}$ & $\begin{array}{c}\text { not present } \\
\text { Halcenit }\end{array}$ & $\begin{array}{l}\text { not } \mathrm{p} \\
\text { Larg }\end{array}$ & $\begin{array}{c}\text { not present } \\
\text { vladeni }\end{array}$ & $\mid \begin{array}{l}\text { not } p \\
\text { not } p\end{array}$ & not present & $\begin{array}{l}\text { sent } \\
\text { sent }\end{array}$ & \\
\hline & & & & & c & & & Vladeni & & & & & $\mid \begin{array}{l}\text { not pp } \\
\text { not }\end{array}$ & $\begin{array}{l}\text { Halceni } \\
\text { of present }\end{array}$ & $\begin{array}{l}\text { not present } \\
\text { not present }\end{array}$ & \\
\hline & & & & & not 1 & $\mathrm{H}_{2}$ & & ent & & & & & & & & \\
\hline & & & & t present & not present & & & not $\mathrm{p}_{\mathrm{p}}$ & $\mathrm{C}_{2}$ & & & & & & & \\
\hline & & & Lar & 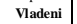 & $\mathrm{Ca}$ & 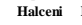 & & Vladeni & $\mathrm{Ca}$ & $\mathrm{Hal}$ & & & & & & \\
\hline & & & & & Carj & & & & & & & & & & & \\
\hline & & & & & not pre & & & Vladeni & not 1 & & & & & & & \\
\hline & & & & & Car & no & & & & & & & & & & \\
\hline $\begin{array}{l}\text { tra avosetta } \\
\text { ia }\end{array}$ & $\begin{array}{l}\text { not present } \\
\text { not resent }\end{array}$ & & & & & & & & & & & & & & & \\
\hline na & not present & Halce & & & & & & & & & & & & & & \\
\hline & & not presen & Larg: & Vladeni & Carja & & & not present & $\mathrm{Ca}$ & & & & & & & \\
\hline & & & & & & & & & & & & & & & & \\
\hline & & & & & & & & & & & & & & & & \\
\hline & & & & & & & & & & & & & & & & \\
\hline & & & & & & & & & & & & & & & & \\
\hline & & & & & & & & & & & & & & & & \\
\hline & & & & & & & & & & & & & & & & \\
\hline & & & & & & & & & & & & & & & & \\
\hline & & & & & & & & & & & & & & & & \\
\hline & & & & & & & & & & & & & & & & \\
\hline & & & & & & & & & & & & & & & & \\
\hline No. of species & $\begin{array}{c}\text { Carja } \\
47\end{array}$ & 53 & $\underset{55}{\text { Larga }}$ & V'adeni & $\mathrm{C}$ & 5 & $\begin{array}{l}\text { Larga Jiji. } \\
57\end{array}$ & not preser & $\begin{array}{l}\text { Caraja } \\
74\end{array}$ & 56 & 48 & 8 & $\begin{array}{c}\text { Carja } \\
40\end{array}$ & 50 & 17 & 6 \\
\hline
\end{tabular}




\section{References}

1. Andrén H (1994) Effects of Habitat Fragmentation on Birds and Mammals in Landscapes with Different Proportions of Suitable Habitat: A Review. Oikos 71(3):355-366. doi: 10.2307/3545823

2. Báldi A (2006) Factors influencing occurrence of passerines in the reed archipelago of Lake Velence (Hungary). Acta Ornithologica 41(1):384-390. doi: 10.3161/068.041.0105

3. Barnagaud JY, Devictor V, Jiguet F, Barbet-Massin M, Le Viol I, Archaux F (2012) Relating Habitat and Climatic Niches in Birds. PLoS ONE 7(3):e32819. doi: 10.1371/journal.pone.0032819

4. Batt DJB, Afton AD, Anderson MG, Ankney CD, Johnson DH, Kadlec JA, et al (1992) Ecology and Management of Breeding Waterfowl. University of Minnesota Press, Minneapolis

5. Benassi G, Battisti C, Luiselli L (2007) Area effect on bird species richness of an archipelago of wetland fragments in Central Italy. Community Ecology 8(2):229237.doi: 10.1556/ComEc.8.2007.2.9

6. Bibby CJ, Burgess ND, Hill DA, Mustoe SH (2000) Bird Census Techniques. $2^{\text {nd }}$ edition. Academic Press, London

7. Bîrsan MV, Zaharia L, Chendeș V, Brănescu E (2014) Seasonal trends in Romanian streamflow, Hydrological Processes 28(15): 4496-4505. doi: 10.1002/hyp.9961

8. Bogaert J, Myneni RB, Knyazikhin Y (2002) A mathematical comment on the formulae for the aggregation index and the shape index. Landscape Ecology 17(1):87-90. doi: 10.1023/A:1015204923187

9. Bolduc F, Afton DA (2008) Monitoring water bird abundance in wetlands: The importance of controlling results for variation in water depth. Ecological Modelling 216(3-4):402-408. doi: 10.1016/j.ecolmodel.2008.05.007

10. Bolenbaugh JR, Krementz DG, Lehnen SE (2011) Secretive marsh bird species co-occurrences and habitat associations across the Midwest, USA. Journal of Fish and Wildlife Management 2(1):49-60. doi:10.3996/012011-JFWM-001

11. Böhning-Gaese K (1997) Determinants of Avian Species Richness at Different Spatial Scales. Journal of Biogeography 24(1):49-60. doi: 10.1111/j.13652699.1997.tb00049.x

12. Celada C, Bogliani G (1993) Breeding bird communities in fragmented wetlands, Bolletino di Zoologia 60(1):73-80, doi: 10.1080/11250009309355794

13. Chettri N, Deb DC, Sharma E, Jackson R (2005) The Relationship between Bird Communities and Habitat - A Study along Trekking Corridor in the Sikkim Himalaya. Mountain Research and Development 25(3): 235-243.doi: 10.1659/0276-4741(2005)025[0235:TRBBCA]2.0.CO;2

14. Colwell MA, Taft OW (2000) Waterbird Communities in Managed Wetlands of Varying Water Depth. Waterbirds. The International Journal of Waterbird Biology 23(1): 45-55. 
15. Crick HQP (1992) A bird-habitat coding system for use in Britain and Ireland incorporating aspects of land management and human activity. Bird Study 39(1): 1-12. doi:10.1080/00063659209477092

16. Dallimer M, Skinner AMJ, Davies ZG, Armsworth PR, Gaston KJ (2012) Multiple habitat associations: the role of offsite habitat in determining onsite avian density and species richness. Ecography 35(2):134-145. doi: 10.1111/j.16000587.2011.07040.x

17. Fairbairn SE, Dinsmore JJ (2001) Local and landscape-level influences of wetland bird communities of the prairie pothole region of Iowa, USA. Wetlands 21(1):4147. doi: 10.1672/0277-5212(2001)021[0041:LALLIO]2.0.CO; 2

18. Garaba L, Sfícă L (2015) Climatic features of the Romanian territory generated by the action of Mediterranean cyclones. Lucrările Seminarului Geografic „,Dimitrie Cantemir" 39(1):11-24. doi: http://dx.doi.org/10.15551\%2Flsgdc.v39i1.1012

19. Gauthreaux SA Jr., Michi JE, Belser GC (2005) The Temporal Spatial Structure of the Atmosphere and its influence on Bird Migration Strategies. In: Greenberg R, Marra PP (ed) Birds of two worlds: the ecology and evolution of migration. The john Hopkins University Press, Baltimore, pp. 183

20. González-Gajardo A, Sepúlveda PV, Schlatter R (2009) Waterbird Assemblages and Habitat Characteristics in Wetlands: Influence of Temporal Variability on Species-Habitat Relationships. Waterbirds 32(2):225-233. doi: 10.1675/063.032.0203

21. Hill MO (1973) Diversity and Evenness: A Unifying Notation and Its Consequences. Ecology 54(2):427-432. doi: 10.2307/1934352

22. Ion I (1992) Glimpses of ornitho-fauna from Prut Valley.Scientific Annals of" Alexandru Ioan Cuza" University of Iași, Animal Biology 37(2):241-242

23. Jongman RHG, Ter Braak CJF, Van Tongeren OFR (1995) Data Analysis in Community and Landscape Ecology, Cambridge University Press, New York

24. Kahara SN, Duffy WG, DiGaudio R, Records R (2012) Climate, Management and Habitat Associations of Avian Fauna in Restored Wetlands of California's Central Valley, USA. Diversity 4(4):396-418. doi: 10.3390/d4040396

25. Katayama N, Amano T, Naoe S, et al. Landscape Heterogeneity-Biodiversity Relationship: Effect of Range Size. Bond-Lamberty B, ed. PLoS ONE. 2014;9(3):e93359. doi:10.1371/journal.pone.0093359.

26. Klein Tank AMG, Wijngaard JB, Können GP, Böhm R, Demarée G, Gocheva A, et al (2002) Daily dataset of 20th-century surface air temperature and precipitation series for the European Climate Assessment. International Journal of Climatology 22(12):1441-1453. doi: 10.1002/joc.773

27. Kaufman, L. and P.J. Rousseeuw (1990). Finding Groups in Data: An Introduction to Cluster Analysis. Wiley, New York.

28. Krebs CJ (1999) Ecological Methodology. 2nd edition. Addison-Wesley Educational Publishers, Inc., Menlo Park

29. Kristan BW, Johnson MD, Rotenberry JT (2007) Choices and consequences of avian habitat selection. The Condor 109(3):485-488. doi: 10.1650/8346.1 
30. Lahti DC (2001) The "edge effect on nest predation" hypothesis after twenty years. Biological Conservation 99(3):365-374. doi: 10.1016/S0006-3207(00)00222-6

31. Le Viol I, Jiguet F, Brotons L, Herrando S, Lindström A, Pearce-Higgins JW, et al (2012) More and more generalists: two decades of changes in the European avifauna. Biology Letters 8(5):780-782. doi: 10.1098/rsbl.2012.0496

32. Lennon JJ, Greenwood JJD, Turner JRG (2000) Bird diversity and environmental gradients in Britain: a test of the species-energy hypothesis. Journal of Animal Ecology 69(4):581-598. doi: 10.1046/j.1365-2656.2000.00418.x

33. Ma Z, Cai Y, Li B, Chen J (2010) Managing Wetland Habitats for Waterbirds: An International Perspective. Wetlands 30(1):15-27. doi: 10.1007/s13157-009-0001-6

34. Magurran AE (1988) Ecological diversity and its measurement. Princeton University Press, Princeton

35. Mattison EHA, Norris K (2005) Bridging the gaps between agricultural policy, land-use and biodiversity. Trends in Ecology and Evolution 20(11):610-616. doi:10.1016/j.tree.2005.08.011

36. Morrison LM (2006) Restoring Wildlife: Ecological Concepts and Practical Applications. Island Press, Washington

37. NaugleDE, Johnson RR, Estey ME, Higgins KF (2000) A Landscape approach to conserving wetland bird habitat in the Prairie Pothole Region of Eastern South Dakota. Wetlands 20(4):588-604. doi: 10.1672/02775212(2000)020[0588:ALATCW]2.0.CO;2

38. Newton I (1998) Populations limitation in birds. Academic Press U.K, London

39. Newton I (2007) Weather-related mass-mortality events in migrants. Ibis 149(3):453-467. doi: 10.1111/j.1474-919X.2007.00704.x

40. O'Hara RB,Kotze JD (2010) Do not log-transform count data. Methods in Ecology and Evolution 1(2):118-122. doi: 10.1111/j.2041-210X.2010.00021.x

41. Oja T, Alamets K, Pärnamets H (2005) Modelling bird habitat suitability based on landscape parameters at different scales. Ecological Indicators 5(4):314-321. doi:10.1016/j.ecolind.2005.03.008

42. Paracuellos M (2008) Effects of long-term habitat fragmentation on a wetland bird community. Revued'Ecologie (Terre Vie) 63:1-12

43. Pearson RG, Dawson TP (2003) Predicting the impacts of climate change on the distribution of species: are bio climate envelope models useful? Global Ecology \& Biogeography 12(5):361-371. doi: 10.1046/j.1466-822X.2003.00042.x

44. Pickett SRA, Siriwardena GM (2011) The relationship between multi-scale habitat heterogeneity and farmland bird abundance. Ecography 34(6):955-969. doi: 10.1111/j.1600-0587.2011.06608.x

45. Preiszner B, Csörgő T (2012) Habitat preference of sylviidae warblers in a fragmented wetland. Acta Zoologica Academiae Scientiarum Hungaricae 54(1):111-122

46. Pulido F (2007) Phenotypic changes in spring arrival: evolution, phenotypic plasticity, effects of weather and condition. Climate Research 35:5-23. doi: $10.3354 / \mathrm{cr} 00711$ 
47. Rehm EM, Baldassarre GA (2007) The influence of interspersion on marsh bird abundance in New York. The Wilson Journal of Ornithology. 119(4):648-654. doi: 10.1676/06-060.1

48. Riffell KS, Keas BE, Burton TM (2001) Area and habitat relationships of birds in Great Lakes coastal wet meadows. Wetlands 21(4):492-507. doi: 10.1672/02775212(2001)021[0492:AAHROB]2.0.CO;2

49. Rondinini C, Wilson KA, Boitani L, Grantham H, Possingham HP (2006) Trade-offs of different types of species occurrence data for use in systematic conservation planning. Ecology Letters 9:1136-1145. doi: 10.1111/j.14610248.2006.00970.x

50. Schaefer HC, Jetz W, Böhning-Gaese K (2008) Impact of climate change on migratory birds: community reassembly versus adaptation. Global Ecology and Biogeography 17(1):38-49. doi: 10.1111/j.1466-8238.2007.00341.x

51. Schipper AM, Koffijberg K, Van Weperen M, Atsma G, Ragas AMJ, Hendriks AJ, et al (2011) The distribution of a threatened migratory bird species in a patchy landscape: a multi-scale analysis. Landscape Ecology 26 (3):397-410. doi: 10.1007/s10980-010-9566-y

52. Skórka P, Martyka R, Wójcik JD (2006) Species richness of breeding birds at a landscape scale: which habitat type is the most important?. ActaOrnithologica 41(1):49-54. doi: 10.3161/068.041.0111

53. Stephens SE, Koonsa DN, Rotellaa JJ, Willey DW (2003) Effects of habitat fragmentation on avian nesting success: a review of the evidence at multiple spatial scales. Biological Conservation 115(1):101-110. doi: 10.1016/S00063207(03)00098-3

54. Tews J, Brose U, Grimm V, Tielbörger K, Wichmann MC, Schwager M, et al. (2004) Animal species diversity driven by habitat heterogeneity/diversity: the importance of keystone structures. Journal of Biogeography 31(1):79-92. doi: 10.1046/j.0305-0270.2003.00994.x

55. Tozer CD, Nol E, Abraham KF (2010) Effects of local and landscape-scale habitat variables on abundance and reproductive success of wetland birds. Wetlands Ecology and Management 18(6): 679-693. doi: 10.1007/s11273-010-9187-x

56. Traut AH, Hostetler ME (2004) Urban lakes and waterbirds: effects of shoreline development on avian distribution. Landscape and Urban Planning 69(1):69-85. doi: 10.1016/j.landurbplan.2003.08.009

57. Triviño M, Thuiller W, Cabeza M, Hickler T, Araújo MB (2011) The Contribution of Vegetation and Landscape Configuration for Predicting Environmental Change Impacts on Iberian Birds. - PLoS ONE 6(12):e29373. doi: 10.1371/journal.pone.0029373

58. Martinez-Vilalta J, Bertolero A, Bigas D, Paquet J-Y, Martinez-Vilalta A (2002) Habitat selection of passerine birds nesting in the Ebro Delta reed beds (NE Spain): management implications. Wetlands 22(2):318-325. doi: 10.1672ş/02775212(2002)022[0318:HSOPBN]2.0.CO;2

59. William L. Thompson W. L. (2002). Towards reliable bird surveys: accounting for individuals present but not detected. The Auk, 119 (1), 18-25 
60. Van Horne, B. (1983). Density as a Misleading Indicator of Habitat Quality. The Journal of Wildlife Management, 47(4), 893-901. doi:10.2307/3808148

61. Weller MW (1999) Wetland Birds: habitat resources and conservation implication. University Press, Cambridge

62. Webb BE, Smith LM, Vrtiska MP, Lagrange TG (2010) Effects of local and landscape variables on wetland bird habitat use during migration through the Rainwater Basin. Journal of Wildlife Management 74(1):109-119. doi: 10.2193/2008-577

63. Wretenberg J, Pärta T, Berg ̊ (2010) Changes in local species richness of farmland birds in relation to land-use changes and landscape structure. Biological Conservation 143(2):375-381. doi: 10.1016/j.biocon.2009.11.001 